\title{
Od pańszczyzny do hipsterstwa Muzyka ludowa między wsią a miastem Z Andrzejem Bieńkowskim rozmawia Piotr Grochowski
}

\author{
From serfdom to hipsterhood \\ Folk music across villages and cities \\ A conversation between Andrzej Bieńkowski \\ and Piotr Grochowski
}

\begin{abstract}
DOI: 10.12775/LL.1.2021.007 | CC BY-ND 3.0 PL
ANDRZEJ BIEŃKOWSKI painter, ethnographer, author of documentary films, professor at the Academy of Fine Arts in Warsaw. Author of the books The Last Country Musicians (2001), The Sold Music (2007) and 10oo Kilometers of Music (2009). Since the 1980s, he and his wife Małgorzata have been conducting ethnographic research, recording and filming rural musicians and singing performances from Poland, Ukraine and Belarus. In 2012, they set up the Muzyka Odnaleziona foundation, which makes their huge archival collections available on CDs as well as on the website www.muzykaodnaleziona.pl and on a YouTube channel. They also implement the Rural Music Archive project (https://archiwummuzykiwiejskiej.pl/), which aims to collect, digitize and make available photographs documenting the musical culture of the countryside.
\end{abstract}

KEYWORDS: folk music, politics, serfdom, World War II, communism, dance houses movement

PG: W ostatnim czasie sporo pisze się o warunkach polityczno-gospodarczych, w jakich przez stulecia kształtowała się w Polsce kultura ludowa, a mianowicie o systemie pańszczyźnianym. Chciałbym zapytać, czy twoim zdaniem pańszczyzna wpłynęła również na specyfikę i sposób funkcjonowania muzyki wiejskiej, a jeśli tak, to czy ten wpływ był jeszcze widoczny w czasie, kiedy prowadziłeś swoje badania.

AB: Tak. Świadomość pańszczyzny była żywa na wsi właściwie jeszcze do końca PRL-u. Taki drobiazg: Mam działkę na wsi. I jak popadłem kiedyśs z sąsiadem w konflikt o miedzę, to największą obelgą, jaką usłyszałem, było: „Ty, kurwa, jesteś dziedzic!”. Inny przykład: W jednej z wsi podgrójeckich, gdzie było dosyć dużo 
dworów, jeszcze w latach 8o. XX w. jak chłopaki grali na zabawach, to grali dworacy kontra chłopi, czyli jeszcze wtedy było coś takiego: pany kontra chamy.

Dziedzictwo pańszczyzny najsilniej widziałem, jak czasami bywałem z „moimi” muzykantami w urzędach. To było niesamowite: ten urzędas, który był - nie wiem - kasjerem czy kimkolwiek, i widać było, że on też jest ze wsi, tylko ma urząd, jak on tych chłopów traktował... jak się chłopi od razu zaczynali zginać w pół i przepraszać, że żyją, i kombinować. Bo to był też cały system obrony chłopów pańszczyźnianych, który polegał z jednej strony na takiej usłużności, z drugiej strony na kąsaniu od tyłu w łydki.

To poczucie gorszości było tak silne, że ja jako nauczyciel akademicki czułem to w tych młodych ludziach, którzy byli już wychowywani w jakichś szkołach w miastach, a potem dostawali się do Akademii Sztuk Pięknych na mój Wydział Wzornictwa - taki dosyć poszukiwany i elitarny - i oni na początku przez długi czas nikomu nie przyznawali się, że są ze wsi. Kłamali. Mówili, że są z miasta, ponieważ wstyd był taki duży. Młodzież używała ciągle określeń typu: „Ty, nie rób wiochy!” albo „Co ty, ubrałeś się w wiochę?!”. To jest wszystko dziedzictwo pańszczyzny. Pańszczyzna została zniesiona 150 lat temu, ale relacje społeczne i kastowość społeczna została w Polsce. I ona się teraz odnawia.

PG: System pańszczyźniany jest jedną z głównych przyczyn tego, że kultura chłopska kształtuje się w warunkach biedy i niedostatku. Czy to ma jakiś bardziej bezpośredni wpływ na muzykę ludową, na gatunki, style wykonawcze, sposoby muzykowania czy instrumentarium?

AB: Moim zdaniem to bardzo zależy od regionu Polski. Pańszczyzny były różne. Była zamożna Wielkopolska i było to biedne, „ciemne” Mazowsze. I to się przejawiało w tym, że właściwie do lat 30. XX w. w Polsce centralnej nie było kapel. Był tylko skrzypek. To się też wiązało z kosztami wesela. Skrzypek miał basy i bęben i na wesele umawiano tylko skrzypka, a on brał skrzypce, basy na plecy i bęben pod pachę. Natomiast goście weselni potrafili bębnić i basować. To było bardzo korzystne dla wszystkich stron, bo lepiej zarabiał skrzypek, mniej płacił pan młody, a ludzie bardzo chętnie basowali i bębnili, bo za to dostawali kieliszek wódki. Zaczęło to wszystko pękać, jak się skończył kryzys gospodarczy w Ameryce, w latach 30. Ameryka wychodząc z tego kryzysu, otworzyła rynek na Europe, w tym na Polskę. Skoczyły ceny ziarna i chłopi zaczęli lepiej zarabiać. I wtedy - jak już były zamożniejsze gospodarstwa - zaczęto się rozglądać za harmoniami. One były już produkowane od dawna, tylko chłopów nie było na nie stać, bo one kosztowały tyle co koń. To jest jedna sprawa. A druga sprawa, że na dawnych weselach dla harmonistów nie było miejsca, bo muzyka spełniała inną rolę. Skrzypek był rodzajem szamana, który wprowadza ludzi w trans i w szaleństwo. Jak się pojawiła harmonia, to nawet najlepsze kapele grały już zwyczajnie „tylko” muzykę. A tamto, to było coś więcej. Te emocje, które ja widziałem - co prawda śladowo, bo już trochę za późno było, ale pare razy widziałem - to było coś niesłychanego, to był prawdziwy trans.

PG: Jakie twoim zdaniem konsekwencje miała II wojna światowa, jeśli chodzi o sytuację wiejskich muzykantów i wiejskie praktyki muzyczne? 
AB: Przede wszystkim, pierwsza niedoceniana konsekwencja to był Holocaust, czyli wymordowanie elit wytwórczych, które pracowały dla wsi. Te małe miasteczka, te różne Grójce, Mogielnice, Nowe Miasta, to były miejsca, gdzie Żydzi nie stanowili mniejszości, tylko byli połową społeczności. To byli bednarze, kołodzieje, krawcy, szewcy, sprzedawcy, komiwojażerzy. To była elita handlowa. I teraz nagle znikają oni z pejzażu: nie ma ci kto butów zrobić, nie ma ci kto wozu naprawić, nie ma ci kto konia podkuć. Nie można zapominać, że to było jednym z poważniejszych powodów zubożenia i zdegradowania wsi.

Niemcy wprowadzili obowiązkowe dostawy. Ciekawostką jest to, że po wojnie komuniści utrzymali ten hitlerowski system obowiązkowych dostaw i on funkcjonował właściwie aż do czasów Gierka. Pytałeś wcześniej o pańszczyznę. Wiesz, kiedy został zniesiony ostatni dekret pańszczyźniany nakazujący chłopom darmową pracę? Nikt prawie nie pamięta - około 1974 r. przez Gierka. To był tzw. szarwark, przepis każący chłopu przez ileś dni w roku pracować za darmo przy budowie drogi. Ten przepis już od pewnego czasu był martwy, ale był. I dopiero Gierek - to w ogóle był największy do tej pory reformator wiejski - kiedy zniósł obowiązkowe dostawy, wprowadził ubezpieczenia społeczne, zniósł również ten szarwark.

Jeśli chodzi o wojnę, to największą uciążliwością nie byli wcale Niemcy. Niemcy wobec wsi zachowywali się pragmatycznie, to znaczy dopóki chłopi nie zabili nikogo z Niemców, to nie reagowali. Namnożyła się za to partyzantka, którą chłopi nazywali chlewikarze. To są właśnie ci „rycerze wyklęci”. To były bandziory, które żyły z tego, że wieczorami rabowali chlewiki. Musieli jeść, musieli pić, musieli się ubrać. To było dosyć powszechne i to było największym problemem. A jednocześnie taki etos narodowy nie pozwalał chłopom zwrócić się o pomoc do Niemców. Oni doskonale wiedzieli, kto jest tym tzw. partyzantem. Partyzanci się wcale nie kryli, ponieważ wiedzieli, że tutaj obowiązuje omerta i chłopi nie doniosą. A ten, który doniósł, to całe jego gospodarstwo zostało natychmiast spalone.

PG: W Ostatnich wiejskich muzykantach wspominasz o tym, że muzykanci chowali się przed partyzantami, którzy zmuszali ich do grania, natomiast chętnie grali dla Niemców. To dość zaskakujący i kłopotliwy fakt.

AB: Piotr Gaca opowiadał przezabawną rzecz. Jako młody chłopak grał na weselu w Potworowie. I było tak strasznie gorąco, więc on sobie pod oknem stanął. Gra na tych skrzypcach i nagle czuje, że z drugiej strony okna łapią go jakieś ręce, wyciągają przez to okno, sadzają na furmankę i chodu... I zawieźli go do lasu. Tam jakieś ognisko się paliło, jakiś baran się piekł. I kazali grać. On się tak wymawia, mówi, że zapłacili mu za wesele. Ale tamci na to: „Graj, kurwa!”. Więc on im pograł. Partyzanci potańczyli, potańczyli (tańczyli między sobą, bo nie było tam dziewcząt) i wzięli go z powrotem na to wesele zawieźli. Ale jak go zawieźli, to już wesela nie było. Goście poczekali ze dwie godziny i... jak to, wesele bez muzyki...

Fakt, o którym wspomniałeś, to autentyczna historia muzykanta z Grójeckiego. Jak przychodzili partyzanci, to oni po prostu szli jak po swoje. Brali go niezależnie od tego, czy miał umówione granie, czy nie, i grosza mu nie zapłacili nawet. A tam niedaleko było lotnisko. I jak Niemcy przyjeżdżali z lotniska, to go brali do kasyna, żeby pograł na harmonii. Nie dawali mu pieniędzy, ale go obdarowywali konserwami 
mięsnymi. To były te wehrmachtowskie, bardzo chwalone konserwy. I on potem w sieni wkopał beczkę i się do niej chował. Jak pukali nocą i kobieta widziała, że partyzanci, to mówiła: „Nie ma, nie ma. Poszedł gdzieś tam grać na wesele”. A jak przychodzili Niemcy, którzy podjeżdżali zwykle jakimś samochodem, to ona waliła w beczkę i wołała: „Wyłaź stary, to nasze, to Niemcy”. Ale finał tej historii był mniej ciekawy, bo on po wojnie miał proces o kolaborację. Dostał chyba dwa lata.

PG: Przejdźmy do czasów PRL-u, kiedy pojawiają się różne formy instytucjonalnych działań i państwowego mecenatu związane z muzyką ludową. Jak oceniasz te działania i jakie konsekwencje dla muzyki wiejskiej miały takie inicjatywy?

AB: To bardzo zależało od regionu, od światłości instruktorów itd. Poza tym nie można tego rozpatrywać tylko politycznie. Te wszystkie rozporządzenia i struktury były tworzone nie przez polityków, tylko przez etnografów z ich XIX-wieczną świadomością tego, kim jest wiejski muzykant. I ta świadomość dla nas dzisiaj jest już czysto egzotyczna. Jak zaczynałem badania, to próbowałem się kontaktować z kwiatem profesorskim etnomuzykologii w Polsce i byłem wstrząśnięty, bo nasłuchałem się wtedy takich bzdur... Podstawowe założenie działania władz PRL-owskich - ja tu mówię o takich działaniach na większą skalę, to znaczy etatach, centralach itp. - było takie: „My niesiemy kaganek oświaty. I ten kaganek niesiemy do prostych ludzi, którzy skądinąd są szlachetni, ale nic nie potrafią. Oni nawet nie potrafią wybrać między dobrem a złem. To co oni robią ma w sobie wielki potencjał, ale dopiero jak my się za to weźmiemy, zrobimy do tego instrumentację, ustawimy głosy, dodamy instruktora baletowego, to będzie to ciekawe i wartościowe”. Przy takim podejściu, muzyka wiejska to jest taki nawóz, z którego dopiero może rozkwitnąc kwiat paproci w postaci zespołu pieśni i tańca. Takich zespołów powstały dziesiątki: Namysłowski, „Śląsk”, „Mazowsze”... Mówimy o tych gigantach, które miały obsadę taką jak Teatr Wielki i Wielka Orkiestra Symfoniczna. Przecież „Mazowsze” miało obsadę beethovenowskiej orkiestry, żeby wykonać muzykę, którą skrzypek grał na jednych skrzypeczkach. Więc to było bardzo ważne w tym pierwszym okresie po wojnie, kiedy wpływy kultury radzieckiej były bardzo silne.

PG: Oprócz działań na wielką skalę, o których mówiłeś wcześniej, władze PRL-u działały też w skali lokalnej, próbując wykorzystywać wiejskich muzykantów do politycznej propagandy.

AB: Jan Ciarkowski, skrzypek kajocki, opowiadał mi taką historię. Rzecz się dzieje w Potworowie. Przed 1 Maja do Ciarkowskiego przyjeżdża komendant policji i mówi: „Ciarkowski, macie się stawić 30 kwietnia na posterunku, tutaj macie papierek i proszę, żebyście byli”. I tak komendant objechał wszystkich skrzypków, nie mówiąc, o co chodzi. Ciarkowski pojechał na ten posterunek. Tam już siedzą inni skrzypkowie, palą papierosy, wchodzi komendant i mówi: „Obywatele, państwo ludowe wzywa was na próbę. My chcemy pokazać światu, że nasza kultura chłopsko-proletariacka jest najważniejsza i wy musicie, obywatele, zagrać na 1 Maja pod trybuną”. Oni trochę zbledli i pytają: „Panie komendancie, ale co?”. On pomyślał i mówi: „Marsza macie zagrać. Tylko pamiętajcie, wróg klasowy nie śpi i jak mi się 
który, kurwa, pomyli, to będzie miał ze mną do czynienia”. Ciarkowski mówi do mnie: „Wie pan, panie Andrzeju, komendant to był taki ludzki pan. Przyniósł litra i kiełbasę. Myśmy wypili tego litra, pojedliśmy kiełbasy i gramy. Gramy, a tu każdy gra w takiej dzikiej tonacji. I nie możemy się zgodzić, bo każdy gra w dzikiej tonacji”. Trzy razy się tak spotykali, w końcu jakoś wyszło. Przychodzi ten 1 Maja i przyjechały takie platformy udekorowane sztandarami, hasłami. Przyjechali UBowcy i dygnitarze partyjni z powiatu. Więc ci stoją tam i pitolą pod tą trybuną tego marsza, ale wróg klasowy nie spał. I stała się rzecz, której nie przewidzieli. Bo ten wróg klasowy nazywał się Drągal. Tam były duże stada krów na łąkach i on te wszystkie krowy zebrał do kupy i w momencie, jak się zaczęły te obchody, to puścił je na trybuny. Jeśli widziałeś kiedyś, jak biegnie spłoszone stado krów, to to jest groźne. I te oszalałe krowy rozpirzyły te dekoracje, to wszystko. Dygnitarze się przestraszyli, wsiedli w samochody i uciekli. Tak wyglądał 1 Maja w Potworowie.

PG: W książce Ostatni wiejscy muzykanci wspominasz, że w czasach PRL-u miała miejsce państwowa weryfikacja zespołów muzycznych i muzykantów. Co to była za akcja?

AB: To jest nie do wiary. To zostało wymyślone w Polskiej Akademii Nauk. Wiem konkretnie przez kogo. Niech mu ziemia lekką będzie, bo już nie żyje. Pojechał samochodem służbowym na wieś i zobaczył, że tam jest zabawa. I jak to wtedy na zabawie - bo to są lata 6o. - jest saksofon, dżaz, akordeon, nie ma skrzypka i nie grają oberka, tylko grają Cicha woda brzegi rwie. No jak to? Cóż za deprawacja tego prostego ludu?! Wobec tego wymyślili, że wszystkie te kapele, które mają grać, muszą przejść przez ministerialną komisję, która da im prawo do tego, żeby grać na wsi. Żeby było lepiej, to dotyczyło również zespołów bigbitowych. Tak samo Czesław Niemen musiał zdać ten egzamin. I wiesz, że nie zdał. Dlatego, że szefem tej komisji był aktor, Kazimierz Rudzki, który go nienawidził i nie dał mu licencji na śpiewanie. I jakie są tego konsekwencje? Jak to na wsi - chłopaki się z dziewczynami spotykają i mówią: „Może byśmy potańczyli? To chodźmy po skrzypka, damy mu pare złotych, usmażymy jajecznicę, potańczymy...”. I poszli do Kazimierza Mety. To jest 1967 lub 1968 r. Kazio oczywiście się zgodził. Dali mu może kieliszek, dali złotówkę na struny i grał. Nagle zajeżdża samochód z ORMO, wchodzi miejscowy ormowiec, łapie go za skrzypce i mówi: „Stop! Stop, orkiestra. Macie pozwolenie? Macie papiery?”. Kazio struchlał przerażony. Przerywają zabawę, ściągają właściciela tej chałupy, podają go do sądu za to, że nie rejestruje tej zabawy i nie zaprasza uprawnionych muzykantów. I w ten sposób Kaziu już nigdy więcej na wsi nie zagrał. Słyszałem o tych weryfikacjach, że tu dużą rolę odegrali właśnie ormowcy, ci lokalni kapusie, bo policja to miała inne rzeczy na głowie. I to było przedstawiane jako wielkie zwycięstwo wysokiej kultury: „Popatrzcie, za tego dziedzica, to można było grać nawet na kupie gnoju, a teraz serce polskiej kultury bije w rytm naszych dyrektyw”.

PG: Czy weryfikacja dotyczyła również ludowych śpiewaczek i śpiewaków?

AB: Nie słyszałem, żeby weryfikacja dotyczyła samego śpiewu. Śpiew siłą rzeczy nie był publiczno-użytkowy. A jeżeli kobiety śpiewały publicznie, np. oczepiny czy 
pieśni maryjne przy kapliczkach - co było w tamtych czasach jeszcze powszechne - to ich to nie dotyczyło.

PG: W okresie PRL-u rozwija się ruch zespołów śpiewaczych, zakładanych np. przy kołach gospodyń wiejskich czy domach kultury. To są działania też jakoś inspirowane i wspierane przez władze komunistyczne, ale ich efekty są chyba raczej pozytywne...

AB: Tak, to jest wielka zasługa, bo gdyby nie koła gospodyń wiejskich to rzeczywiście te kobiety byłyby rozproszone i pozbawione motywacji do działania, bo nie miałyby dla kogo śpiewać. I rzeczywiście są całe regiony w Polsce, gdzie to przyniosło wspaniałe rezultaty, np. Lubelszczyzna czy Roztocze. Te zespoły śpiewacze z Roztocza, to po prostu rewelacja. I one wszystkie funkcjonowały w ramach domów kultury. Wydaje mi się, że jeśli chodzi o takie zespoły, to im dalej na północ Polski, tym większa była w nich rola instruktorów. Może dlatego, że tam te tradycje śpiewu nie były takie silne. Bo jednak Lubleszczyzna to jest Wschód, a te tradycje wschodnie, to są tradycje śpiewu.

Obserwując działalność zespołów śpiewaczych, spotykałem się i z dobrymi, i ze złymi przykładami, ale na ogół to było dobre. Na czym polegał problem? Wielokrotnie miałem do czynienia z taką sytuacją - np. w województwie łódzkim - że jest niezły zespół śpiewaczy, ale mają już kłopoty z repertuarem. I przyjeżdża do nich instruktor, magister z miasta Łodzi, i zamiast te kobiety wysłać na wieś i powiedzieć: „Proszę pani, przecież pani sąsiadka śpiewa. Niech pani ją poprosi i spisze od niej te melodie, te słowa...”, to przywozili gotowe ksera jakichś rzeczy spisanych przez ekipę Sobieskich w latach 50. A rzecz dzieje się na początku lat 9o. i te kobiety już nawet nie potrafiły zaśpiewać tych rzeczy, tak im były obce w sensie interpretacji melodycznej, bo się tak zmieniło to wszystko. A my jeździliśmy po tej okolicy i nagrywaliśmy wspaniałe śpiewaczki. I potem spotkałem kobiety z tego zespołu i dałem im pełną listę tych śpiewaczek i powiedziałem: „Proszę, pójdźcie do nich, zobaczcie”. Nie wiem, jak to się skończyło... I to jest ta druga strona medalu.

PG: Co się dzieje z muzyką ludową po roku 1989? Jak twoim zdaniem na sytuację wiejskich śpiewaków i muzykantów wpływają zmiany polityczne, gospodarcze i kulturowe, które wiążą się $\mathrm{z}$ wprowadzeniem demokracji, nastaniem kapitalizmu i wejściem Polski do Unii Europejskiej?

AB: Trzeba zacząć od tego, że już w latach 50. i 6o. muzyka wiejska całkowicie przeorientowała się pod względem instrumentarium. Wtedy może jeszcze nie było za dużo elektroniki, były pierwsze wzmacniacze, nie było klawiszy, które później bardzo zrewolucjonizowały muzykę wiejską. Ale rzecz polegała na tym, że moda już była taka, że nikt z młodych ludzi - a przecież muzyka jest dla młodych - nie uczył się grać na żadnym z tradycyjnych instrumentów. Dopiero gdy stworzyłem pokaźną bazę nazwisk muzykantów i ich biogramów, zorientowałem się, że ostatni młodzieńcy, którzy uczyli się grać na skrzypcach, byli urodzeni w latach 30. XX w. I teraz mówimy o latach 8o. i 9o., kiedy ci ludzie są jeszcze w pełni sił, mają 50-6o lat. I są skrajnie sfrustrowani, że nikt ich nie chce. Ani w mieście, ani na wsi. To 
w ogóle czarny okres dla kultury polskiej. Lata 8o. i stan wojenny to była jednak wielka smuta, a potem przychodzi odzyskanie niepodległości i też trudny okres. To jest też czas, kiedy nie ma jeszcze w Polsce ruchu domów tańca. Owszem, jest taki jeden wąski strumyczek. Tu trzeba oddać sprawiedliwość festiwalowi w Kazimierzu i instruktorom, którzy w tym okresie tam te gwiazdy wiejskiej muzyki wysyłali raz do roku, raz na dwa lata. Ale w tym momencie tak naprawdę tradycyjna wieś zamilkła. Wtedy na weselach pojawiło się disco polo, pojawiły się nagrania. W radiu zaczęto likwidować audycje z muzyką wiejską, której i tak było bardzo mało, np. zlikwidowali wspaniałą audycję Piotra Gana w Radiu Kielce. Na wiele lat drastycznie ograniczono też nadawanie Programu 2 Polskiego Radia, przez co stracił on swoje znaczenie i słuchaczy. Trudno to zrozumieć. I rzeczywiście, to był taki okres dzikiego bezhołowia. Być może musieliśmy tę cenę zapłacić, bo potem wieś zaczęła wychodzić z tego kryzysu. Uważam, że wieś, która była generalnie przeciwna wejściu do Unii, najwięcej na tej Unii zyskała, i to pod każdym względem - i materialnie, i kulturowo, ale też pod względem kultury agrarnej, bo pojawiły się nowoczesne maszyny i metody upraw.

Myślę, że przełomowym momentem, jeśli chodzi o muzykę wiejską po roku 1989, było powstanie ruchu domów tańca. To była taka kula śniegowa, która zaczęła się toczyć bardzo skromnie, bo tą iskrą był tak naprawdę zespół Bractwo Ubogich, istniejący w latach 1992-1994. Ale potem ta kula śniegowa powoli się powiększała. Pamiętajmy, że dla każdego artysty bardzo ważne jest to, że się czuje potrzebny. I jak nagle do tych wiejskich muzykantów zaczęli jeździć młodzi ludzie z miasta, prosić ich o grę, głaskać po rękach i mówić „Jak pięknie pan gra!”, to oni w ogóle byli osłupiali. A jeszcze jak przyjechali do Warszawy i zobaczyli, że tutaj ludzie tańczą! Przecież na wsi ich wyśmiewano. I w tym momencie zaczęło się to odnowienie.

Ciekawe jest to, że w nurcie domów tańca nie ma muzykologów i nie ma etnografów. Sposób nauczania muzykologii i etnografii w Polsce jest tak nieprzystający do oczekiwań społecznych i do zmian kulturowych, że to jest porażające. Przez tyle lat co roku każda uczelnia kształciła tych ludzi, a ja nigdy nie spotkałem ich w terenie. To jest też przykład takiej dziedziny zdeprawowanej. Złośliwie mogę powiedzieć, że przez dziesiątki lat w Polsce etnomuzykologii uczyły osoby nie lubiące polskiej wsi, nastawione na muzykę egzotyczną. Dopiero w latach 7o. pojawia się Piotr Dahlig i to był wtedy jedyny znanym mi badacz, który robił poważne badania terenowe. Jeszcze oddam sprawiedliwość drugiej osobie: to był Marian Domański $\mathrm{z}$ radia, on też jeździł, nagrywał i robił wspaniałe reportaże. A więc ci młodzi ludzie z domów tańca musieli sami dojść do takiej wiedzy, do jakiej nikt z profesjonalnych etnomuzykologów nie doszedł. I dlatego jestem dla nich pełen wielkiego uznania. Oni znają też te wszystkie tajniki, sztuczki muzykanckie, które decydują o sposobie trzymania skrzypiec, gry, ozdabiania. Zobacz, jaką wiedzę ma np. Janusz Prusinowski. Pamiętam jego audycję o mazurkach Kazimierza Mety, którą powinien zobaczyć każdy, kto gra na skrzypcach, żeby zrozumieć, co to znaczy grać mazurka.

PG: Ruch domów tańca jest zjawiskiem oddolnym i nie był on inspirowany ani też - przynajmniej w początkowej fazie - specjalnie wspierany przez instytucje państwowe. Można więc powiedzieć, że w tym przypadku muzyka ludowa rozwija się niezależnie od oficjalnych działań władz. Takie działania są jednak podejmowane. 
Na przykład reforma administracyjna z 1999 r. sprawiła, że samorządy otrzymały znaczne kompetencje (także środki finansowe) w zakresie kształtowania lokalnej polityki kulturalnej. Czy to się jakoś przełożyło na docenienie muzyki ludowej i zmiane jej rangi na szczeblu regionalnym.

AB: Opowiem ci dwie historie. Potworów - jedna z najbogatszych gmin w Polsce. Hektary nowoczesnego ogrodnictwa, holenderskiej myśli agrarnej i miliony zysków z uprawy papryki. Są tam ogromne imprezy pt. „Dzień papryki”, dofinansowywane przez Unię Europejską. Wielka rockowa scena, targi maszyn rolniczych, traktory, które wyglądają piękniej niż Rolls-Royce, piwo się leje, występuje zespół Toples... dzieje się to wszystko na stadionie. Przyjeżdżam tam, kiedy jest jeszcze dość wcześnie i pusto. Jacyś ludzie siedzą na poboczach tego stadionu i piją piwo, a na tej pustej murawie, jakieś 20 metrów od tej wielkiej sceny stoi jeden staruszek. Zaciekawiło mnie to. Podchodzę do niego, patrzę, a to Piotr Gaca. Miał wtedy 89 lat. Ucieszyłem się i mówię do niego: „Panie Piotrze, jak fajnie że Pana zaprosili, żeby Pan pograł”. A on mówi: „Nie, nie zaprosili mnie. Tak sobie przyjechałem, ale chętnie bym im pograł”. Ja na to: „A nie proponowali?”. A on: „Nie, ale mam taką prośbę, panie Andrzeju, jak pan będzie z nimi rozmawiał... Ja nie chce pieniędzy za granie, ale mogliby mi zapłacić 50 zł za podróż, bo ja wynająłem sąsiada, żeby mnie tu przywiózł”. Serce mi się ścisnęło. Zespół Toples dostał 35 ooo za występ, a oni 50 zł żałowali największemu obywatelowi swojej gminy, obywatelowi, o którym się uczy młodzież na uniwersytetach, którego można usłyszeć w radiu. Skończyło się to tak, że on sobie pojechał. Nie zapłacili mu.

Drugi przykład. Na stadionie w Wyśmierzycach zrobiliśmy 10 lat temu imprezę na najwyższym w Polsce poziomie. Zaprosiliśmy najlepsze kapele - ze wsi, z domów tańca, także z Ukrainy. Dostaliśmy na to grant z Ministerstwa Kultury. Przyszło 10 ooo osób i naprawdę było wspaniale, wszyscy byli zadowoleni. W następnym roku idę do burmistrza i mówię: „To co, robimy imprezę?”. A on mówi: „Dobra, zobaczymy...”. Ale już widzę, że coś nie gra. Dzwoni do mnie po paru dniach i mówi: „Jest taka sprawa. Ksiądz powiedział, że udzieli zgody pod warunkiem, że on przed imprezą na stadionie odprawi msze”. Na co ja mówię: „Co on, w Jana Pawła się bawi!? Tu przyjeżdżają prawosławni. Mowy nie ma”. I wtedy wyszło szydło z worka, bo ci radni na następnym zebraniu mówią burmistrzowi tak: „My tu podtrzymujemy nasze tradycje miejskie, a tu przyjeżdża taki Bieńkowski i chce wiochę nam robić. My chcemy, żeby tu przyjechał ktoś z telewizji. Niech przyjedzie Makłowicz i pokaże, jak się gotuje. Niech przyjedzie zespół Topless i ktoś z telewizji. My nie jesteśmy wiocha”. I tak się skończyła moja współpraca z tą gminą.

Tak więc do wyjątków należy to, że np. burmistrz miasta Odrzywół dwa lata temu zgodził się i pomógł finansowo oraz logistycznie w zorganizowaniu Dnia Bogusza w Kamiennej Woli. Była to skromna, kameralna i bardzo udana impreza. Ja byłem bardzo zadowolony. Miejsce, pamięć i „kult” tego Bogusza... to wszystko do siebie pasowało. I teraz co się dzieje? Idę do tego burmistrza, a on mówi do mnie: „Wie Pan, ja jestem bardzo zadowolony. Ja bardzo chętnie będę z wami współpracował, ale pod warunkiem, że to nie będzie w tej Kamiennej Woli”. A ja mówię: „Jak to?! Proszę pana, ale inaczej to nie ma sensu. To tak jakby robić dni Krakowa w Poznaniu”. A on mówi: „Proszę pana, ja ich mam dosyć. Po tej imprezie oni się 
wszyscy pokłócili o podział łupów. Strażacy z kołem gospodyń, koło gospodyń z sołtysem, a sołtys z burmistrzem. Ja bardzo chcę z panem współpracować, ale teraz zrobimy dni Krakowa w Poznaniu”.

Więc to jest druga strona medalu tej reformy samorządowej. Samorządy muszą dorosnąć. Trzeba też zwrócić uwage na to, że to są rejony, gdzie kilka samorządów, z którymi współpracowałem i już więcej nie będę, podpisało dokumenty w sprawie utworzenia stref wolnych od LGBT. Te haniebne inicjatywy wychodziły od miejscowych dorobkiewiczów i Kościoła. Takie też są u nas samorządy.

PG: Na koniec chciałbym cię zapytać o film Agonia w reżyserii Tomasza Knittla, który miał nie tak dawno premierę i wzbudził spore zainteresowanie wśród miłośników tradycyjnej muzyki wiejskiej. Adam Strug, który jest autorem scenariusza i zarazem narratorem, stawia w nim tezę, że mamy dziś do czynienia z ostatecznym końcem muzyki ludowej w jej oryginalnej postaci. Ty nie zgadzasz się $\mathrm{z}$ nim w tej kwestii. Dlaczego? Jaka jest twoim zdaniem przyszłość muzyki ludowej?

AB: Gdyby Adam robił ten film 10 lat temu, to jam bym powiedział: „Masz racje”. Rzuciłbym mu się w ramiona i razem byśmy sobie popłakali. Ale to, co się dzieje teraz, napawa mnie wielkim optymizmem. Widzę tu jeden zasadniczy mechanizm. Przez ostatnie lata obawiano się, że proces cywilizowania i europeizacji naszego kraju - ciemnego, zacofanego, patriarchalnego - przekształcania go w nowoczesne społeczeństwo obywatelskie spowoduje odejście od tradycji. Stało się coś dokładnie odwrotnego. Im więcej u nas było Europy, dumy i braku kompleksów z powodu tego, że byliśmy zapyziałą katolicko-narodową Polską, tym chętniej sięgaliśmy do wzorców starej kultury, ale już w europejskim kontekście. W innych krajach też możemy obserwować bardzo podobne procesy, ale w Polsce ten proces jest specjalny i myślę, że wyjątkowy. Stało się bowiem kilka rzeczy. Po pierwsze, ci młodzi ludzie, którzy zaczęli się interesować muzyką wiejską, zrobili to w ostatniej chwili, kiedy mogli jeszcze uczyć się u muzykantów wychowanych na tradycyjnej wsi. I to jest bezcennym naszym doświadczeniem, którego nie miały inne kraje. Poza tym widzę, że to zjawisko wyszło poza getto domów tańca i zaczęło się rozszerzać. Oczywiście wieś tu jest ważna. Ale ruch muzyczny, o którym mówię, tak się już wyemancypował, że wieś jest mu potrzebna tylko do stymulacji. Wieś nie jest niezbędna do istnienia tej muzyki, bo tej muzyki na wsi właściwie już nie ma. Naprawdę na palcach jednej ręki można policzyć tych, którzy na wsiach w Polsce centralnej są rzeczywiście mistrzami i mogą jeszcze uczyć. Reszta dzisiejszych wiejskich muzykantów to są ludzie douczeni. To jest oczywiście cenne, że oni grają, ale oni grają gorzej niż ci młodzi z miasta... I to jest to, co napawa mnie ogromnym optymizmem, bo ten miejski ruch muzyki tradycyjnej powoli staje się taką kulturą młodzieżową. Co prawda niszową, ale już zauważalną. To jest taki rodzaj specjalnego hipsterstwa.

PG: Muzyka ludowa będzie więc żyć w mieście, a nie na wsi.

AB: Tak. Ale ja uważam, że ona będzie coraz bardziej inkorporowana na wieś. I kiedy przestanie się z nią wiązać ta otoczka obciachu, to ona wróci. Kiedy parę lat temu na wsiach organizowaliśmy zabawy z tradycyjnymi kapelami i przychodziła 
na nie miejscowa młodzież, to oni własnym oczom nie wierzyli, że do tej muzyki można tańczyć. Oni tę muzykę znali, bo to przecież muzyka ich ojców. A tu takie ładne dziewczyny i chłopaki z miasta, i oni do tej muzyki tańczą?! Jeden mówi: „Ja bym ze wstydu się spalił, gdybym miał coś takiego zatańczyć”. Sytuacja tej muzyki na wsi zmieni się, jeżeli będzie się z nią wiązało pojęcie awansu kulturowego, jeżeli oni zobaczą, że przez tę muzykę mają dostęp do miasta, do tych dziewczyn, do tych chłopaków... To będzie wielkim bodźcem, bo wieś jest zdolna, tam jest kupa potencjalnych muzyków. Nawet znam kilku, którzy by chcieli, ale się krępują. Oni trochę się uczą. Przyjeżdżali tutaj nawet na te warsztaty do domu tańca, ale mówią: „Wie pan, na wsi to ja tak nie bardzo mogę kogoś do bębnienia namówić" itd. Więc ten obciach jeszcze jest, ale to jest trend zanikający i dlatego jestem optymistą. 